\title{
Pengaruh pelaksanaan pelatihan developmentally appropriate practice terhadap peningkatan kompetensi pedagogik pendidik PAUD
}

\author{
Fitri Pertiwi *, Ishak Abdulhak, Viena Rusmiati Hasanah \\ Pendidikan Luar Sekolah, Sekolah Pascasarjana, Universitas Pendidikan Indonesia. \\ Jalan Setiabudhi No. 229, Bandung, Jawa Barat 40154, Indonesia \\ * Corresponding Author. Email: fitripertiwi@student.upi.edu \\ Received: 28 June 2018; Revised: 31 October 2018; Accepted: 3 December 2018
}

\begin{abstract}
Abstrak
Penelitian ini bertujuan untuk mengetahui pengaruh pelaksanaan pelatihan Developmentally Appropriate Practice (DAP) terhadap peningkatan kompetensi pedagogik pendidik PAUD. Penelitian ini menggunakan metode ex post-facto dengan pendekatan kuantitatif. Data dalam penelitian ini dikumpulkan melalui angket dan studi dokumentasi. Pengaruh pelaksanaan pelatihan Developmentally Appropriate Practice (DAP) diidentifikasi melalui perbandingan rata-rata antara data pre-test dan data post-test. Angket juga dikumpulkan lalu dianalisis untuk mengetahui gambaran pelaksanaan pelatihan Developmentally Appropriate Practice (DAP) dan gambaran kompetensi pedagogik pendidik PAUD setelah mengikuti pelatihan Developmentally Appropriate Practice (DAP). Hasil penelitian menunjukkan bahwa setelah mengikuti pelaksanaan pelatihan Developmentally Appropriate Practice (DAP), rata-rata kompetensi pedagogik pendidik PAUD menjadi lebih baik dibandingkan dengan sebelum mengikuti pelaksanaan pelatihan Developmentally Appropriate Practice (DAP), atau dengan kata lain pelaksanaan pelatihan Developmentally Appropriate Practice (DAP) berpengaruh secara signifikan terhadap peningkatan kompetensi pedagogik pendidik PAUD.
\end{abstract}

Kata Kunci: pelatihan developmentally appropriate practice (DAP), kompetensi pedagogik, pendidik PAUD.

\section{The influence of developmentally appropriate practice training program on improving early childhood education teachers' pedagogical competence}

\begin{abstract}
This study aims to investigate the influence of the Developmentally Appropriate Practice (DAP) training program on improving preschool teachers' pedagogical competence. The study used quantitative approach with ex post-facto as its method. The data are collected by using questionnaires and documentation study. The influence of the Developmentally Appropriate Practice (DAP) training program is identified through a comparison of the average mean score between pre-test and post-test. Questionnaires was also collected and analyzed to find out the process of Developmentally Appropriate Practice (DAP) training program and also to know the preschool teachers' pedagogical competence after joining the Developmentally Appropriate Practice (DAP) training program. The findings revealed that after joining the Developmentally Appropriate Practice (DAP) training program, the average level of the teachers' pedagogical competence improves. In other words, the Developmentally Appropriate Practice (DAP) training program has a significant influence on improving the preschool teachers' pedagogical competence. Keywords: Developmentally Appropriate Practice (DAP) training program, pedagogical competence, early childhood education teachers.
\end{abstract}


JPPM (Jurnal Pendidikan dan Pemberdayaan Masyarakat), 5 (2), 2018 - 143

Fitri Pertiwi, Ishak Abdulhak, Viena Rusmiati Hasanah

How to Cite: Pertiwi, F., Abdulhak, I., \& Hasanah, V. (2018). Pengaruh pelaksanaan pelatihan developmentally appropriate practice terhadap peningkatan kompetensi pedagogik pendidik PAUD. JPPM (Jurnal Pendidikan dan Pemberdayaan Masyarakat), $\quad$ 5(2), $142-153$. doi:https://doi.org/10.21831/jppm.v5i2.20124

https://doi.org/10.21831/jppm.v5i2.20124

\section{PENDAHULUAN}

Pendidikan merupakan faktor yang sangat penting dalam pembangunan suatu bangsa (Purwanto, 2006; Syamsidar, 2014). Pengembangan sumber daya manusia saat ini pun sangat dipengaruhi pula oleh kualitas pendidikan itu sendiri. Sehingga maju atau tidaknya suatu bangsa dapat dilihat dari pengembangan sumber daya manusia yang ada dalam bangsa tersebut. Sumber daya manusia ini hendaknya sudah dipersiapkan jauh-jauh hari yaitu dengan memberikan perhatian yang besar pada pendidikan anak sejak anak masih dalam masa usia dini. Dengan demikian, pendidikan anak usia dini memiliki peran yang sangat penting dalam membantu anak untuk mengenal serta mengembangkan potensi-potensi yang dimiliki oleh anak. Oleh karena itu, kurikulum yang digunakan serta perencanaan pembelajaran yang disusun pada pendidikan anak usia dini hendaknya disesuaikan dengan tahapan perkembangan anak, agar tugastugas pada setiap tahapan perkembangan anak dapat terpenuhi.

Pendidik mempunyai peran yang sangat penting dalam menyukseskan kegiatan belajar mengajar di dalam kelas. Pendidik pun harus mengerti bahwa setiap anak mempunyai bakat, minat, kelebihan, kekurangan, serta pengalaman yang berbeda-beda. Maka dari itu, pendidik hendaknya dapat menyesuaikan diri dengan keunikan-keunikan tersebut (Lidinillah, 2012, p. 1). Mengingat pentingnya hal tersebut, pendidik dituntut untuk memahami pendekatan yang relevan dengan tahapan perkembangan anak. Salah satu konsep yang relevan dengan pendekatan perencanaan pembelajaran yang sesuai dengan tahapan perkembangan anak adalah konsep Developmentally Appropriate Practice (DAP) atau bila diartikan ke dalam bahasa Indonesia yaitu pendidikan yang sesuai dengan tahapan perkembangan anak.
Pelatihan merupakan suatu solusi bagi para pendidik untuk meningkatkan pengetahuan serta keterampilannya dalam melaksanakan tugas dan tanggung jawab profesinya. Sudjana (2007, p. 7) mengemukakan bahwa, "Kegunaan pelatihan bagi peserta pelatihan adalah terjadinya peningkatan kemampuan melalui perolehan keterampilan, pengetahuan, sikap, dan nilai-nilai baru setelah mengikuti pelatihan, yang ditampilkan dalam pelaksanaan tugas atau pekerjaan dan/atau kehidupan mandiri”. Munculnya pelatihan sebagai suatu wadah dalam berbagi ilmu dan meningkatkan pengetahuan seorang individu diharapkan dapat membantu pendidik dalam menjalankan tugasnya serta untuk meningkatkan kualitas diri pendidik itu sendiri.

Berdasarkan hasil Uji Kompetensi Awal (UKA) yang dilaksanakan oleh Kementerian Pendidikan dan Kebudayaan diperoleh data bahwa penguasaan kompetensi pendidik TK/PAUD yaitu sebesar 58,87 dari batas nilai yang ditetapkan oleh pemerintah yaitu 70 . Angka tersebut menunjukkan bahwa penguasaan kompetensi pendidik TK/PAUD masih rendah (Zustiyantoro, 2012). Oleh karena itu, diperlukan suatu kegiatan pembinaan agar penguasaan kompetensi pendidik dapat meningkat dan menjadi lebih baik lagi.

Faktor-faktor yang memiliki keterkaitan dengan kompetensi pedagogik pendidik di antaranya latar belakang pendidikan pendidik, pengalaman pendidik dalam mengajar, kesehatan pendidik, penghasilan pendidik, sarana pendidikan, kedisiplinan pendidik dalam bekerja, pengawasan kepala sekolah, organisasi keguruan, serta kursus kependidikan (Wibowo, 2009, p. 28). Pelatihan Developmentally Appropriate Practice (DAP) merupakan salah satu bagian dari kursus kependidikan. Dengan demikian, pelatihan Developmentally Appropriate Practice (DAP) memiliki keterkaitan dengan kompetensi pedagogik pendidik. 
JPPM (Jurnal Pendidikan dan Pemberdayaan Masyarakat), 5 (2), 2018 - 144

Fitri Pertiwi, Ishak Abdulhak, Viena Rusmiati Hasanah

Pelatihan Developmentally Appropriate Practice (DAP) dilaksanakan untuk meningkatkan kualitas diri setiap pendidik PAUD serta untuk menambah pengetahuan pendidik PAUD mengenai pendekatan pembelajaran yang sesuai dengan tahapan perkembangan anak agar kegiatan pembelajaran yang dilaksanakan dapat mengembangkan serta mengoptimalkan potensi peserta didik. Pelaksanaan pelatihan Developmentally Appropriate Practice (DAP) atau pendidikan yang patut berdasarkan tahapan perkembangan anak pada hakikatnya dapat membantu pendidik PAUD dalam melakukan pendekatan pembelajaran yang sesuai dengan tahapan perkembangan anak. Dengan mengikuti pelatihan Developmentally Appropriate Practice (DAP), pendidik dapat menyusun perencanaan pembelajaran yang tepat sesuai dengan tahapan perkembangan setiap anak, memahami karakteristik juga keunikan-keunikan yang dimiliki setiap anak, mengetahui serta mengembangkan potensi anak, dan pada akhirnya dapat membantu anak dalam mencapai potensi yang dimilikinya secara optimal.

Berdasarkan hal tersebut, maka kegiatan penelitian ini memfokuskan penelitian pada pengaruh pelaksanaan pelatihan Developmentally Appropriate Practice (DAP) terhadap peningkatan kompetensi pedagogik pendidik PAUD. Tujuan dari penelitian ini untuk mengetahui pengaruh pelaksanaan pelatihan Developmentally Appropriate Practice (DAP) terhadap peningkatan kompetensi pedagogik pendidik PAUD.

\section{METODE}

Metode yang digunakan di dalam penelitian ini yaitu metode ex post-facto dengan pendekatan kuantitatif. Metode ex post-facto yang berarti "setelah fakta", menurut Emzir (2009, p. 119) yaitu "Penyelidikan empiris yang sistematis di mana ilmuwan tidak mengendalikan variabel bebas secara langsung karena eksistensi dari variabel tersebut telah terjadi atau karena variabel tersebut pada dasarnya tidak dapat dimanipulasi”. Pelaksanaan pelatihan Developmentally Appropriate Practice (DAP) dalam penelitian ini telah terjadi sebelumnya, sehingga peneliti tidak perlu memberikan perlakuan lagi namun tinggal melihat efeknya pada peningkatan kompetensi pedagogik pendidik PAUD melalui data pretest dan post-test.

Populasi di dalam penelitian ini yaitu 100 orang peserta pelatihan DAP dengan sampel sebanyak 6o orang melalui teknik simple random sampling. Instrumen penelitian yang digunakan dalam penelitian ini yaitu angket dan studi dokumentasi. Angket digunakan untuk mengetahui gambaran pelaksanaan pelatihan Developmentally Appropriate Practice (DAP) yang dilihat dari aspek pelaksanaannya saja, serta untuk mengetahui kompetensi pedagogik pendidik PAUD setelah mengikuti pelatihan Developmentally Appropriate Practice (DAP). Studi dokumentasi digunakan untuk memperoleh data mengenai daftar nama peserta pelatihan, materi pelatihan Developmentally Appropriate Practice (DAP), soal pre-test dan post-test pelatihan, dan perolehan nilai pretest dan post-test peserta. Analisis data yang digunakan yaitu uji perbedaan dua rata-rata populasi berhubungan, untuk membandingkan perubahan yang terjadi antara sebelum dan setelah para peserta pelatihan yang merupakan para pendidik PAUD mengikuti pelaksanaan pelatihan Developmentally Appropriate Practice (DAP), yang diukur melalui data pre-test dan data post-test.

\section{HASIL DAN PEMBAHASAN}

Pada bagian ini disajikan mengenai hasil dan pembahasan penelitian yang berkaitan dengan tujuan penelitian. Adapun uraiannya sebagai berikut.

\section{Pelaksanaan Pelatihan Developmentally Appropriate Practice (DAP) di UPTD Pendidikan Kecamatan Nagrak Kabupaten Sukabumi}

Hasil penelitian menunjukkan bahwa pelaksanaan pelatihan Developmentally Appropriate Practice (DAP) di UPTD Pendidikan Kecamatan Nagrak Kabupaten Sukabumi berdasarkan indikatornya yang terdiri dari kegiatan menyeleksi peserta pelatihan, pelaksanaan penilaian awal terhadap peserta pelatihan, pelaksanaan program 
JPPM (Jurnal Pendidikan dan Pemberdayaan Masyarakat), 5 (2), 2018 - 145

Fitri Pertiwi, Ishak Abdulhak, Viena Rusmiati Hasanah

pelatihan, pengawasan selama proses pelaksanaan program pelatihan, dan pelaksanaan penilaian akhir peserta program pelatihan dengan jumlah responden sebanyak 60 orang, yaitu dari 50 orang responden dengan jumlah persentase sebesar 83,33\% menunjukkan bahwa pelaksanaan pelatihan Developmentally Appropriate Practice (DAP) berada pada kategori sangat tinggi, dari 10 orang responden dengan jumlah persentase sebesar 16,67\% menunjukkan bahwa pelaksanaan pelatihan Developmentally Appropriate Practice (DAP) berada pada kategori tinggi, sedangkan pada kategori sedang, rendah, dan sangat rendah tidak ada responden yang memilih kategori tersebut sehingga persentasenya $\mathrm{o} \%$. Adapun gambarannya dapat dilihat pada Table 1.

Tabel 1. Pelaksanaan Pelatihan DAP di UPTD Pendidikan Kecamatan Nagrak Kabupaten Sukabumi

\begin{tabular}{|c|c|c|c|}
\hline Kriteria & Interval & $\mathrm{F}$ & $\%$ \\
\hline Sangat Tinggi & $X>84$ & 50 & 83.33 \\
\hline Tinggi & $70<X \leq 84$ & 10 & 16.67 \\
\hline Sedang & $56<X \leq 70$ & O & 0.00 \\
\hline Rendah & $42<X \leq 56$ & o & 0.00 \\
\hline Sangat Rendah & $X \leq 42$ & o & 0.00 \\
\hline \multicolumn{2}{|c|}{ Total } & 60 & 100 \\
\hline
\end{tabular}

Pelaksanaan pelatihan Developmentally Appropriate Practice (DAP) dalam penelitian ini diukur melalui tanggapan para peserta pelatihan terhadap pelaksanaan pelatihan Developmentally Appropriate Practice (DAP) yang dilaksanakan di UPTD Pendidikan Kecamatan Nagrak Kabupaten Sukabumi. Hal yang diukur guna mengetahui pelaksanaan pelatihan Developmentally Appropriate Practice (DAP) di UPTD Pendidikan Kecamatan Nagrak Kabupaten Sukabumi yaitu kegiatan menyeleksi peserta pelatihan, pelaksanaan penilaian awal terhadap peserta pelatihan, pelaksanaan program pelatihan, pengawasan selama proses pelaksanaan program pelatihan, dan pelaksanaan penilaian akhir peserta program pelatihan.

Hal ini sejalan dengan pendapat Sudjana (2007, p. 12) bahwa fungsi pelaksanaan mencakup melakukan seleksi peserta pelatihan, melaksanakan penilaian awal terhadap peserta pelatihan agar diketahui kemampuan awal peserta sebelum mengikuti pelatihan, melaksanakan pelatihan, mengawasi proses pelaksanaan program pelatihan, dan melakukan penilaian akhir terhadap peserta pelatihan untuk mengetahui peningkatan pengetahuan peserta setelah mengikuti program pelatihan.

Berdasarkan keseluruhan indikator dari pelaksanaan pelatihan Developmentally Appropriate Practice (DAP) di UPTD Pendidikan Kecamatan Nagrak Kabupaten Sukabumi dapat dikatakan bahwa proses pelaksanaan pelatihan berjalan dengan sangat baik. Hal ini dibuktikan dengan hasil analisis data yang telah dilakukan yaitu bahwa pelaksanaan pelatihan Developmentally Appropriate Practice (DAP) di UPTD Pendidikan Kecamatan Nagrak Kabupaten Sukabumi dengan jumlah responden sebanyak 6o orang, yaitu dari 50 orang responden dengan jumlah persentase sebesar 83,33\% menunjukkan bahwa pelaksanaan pelatihan Developmentally Appropriate Practice (DAP) berada pada kategori sangat tinggi, dan dari 10 orang responden dengan jumlah persentase sebesar $16,67 \%$ menunjukkan bahwa pelaksanaan pelatihan Developmentally Appropriate Practice (DAP) berada pada kategori tinggi. Jumlah persentase yang rata-rata berada pada kategori sangat tinggi dan tinggi dari setiap indikator pun dapat menjadi pendukung tambahan bahwa pelaksanaan pelatihan Developmentally Appropriate Practice (DAP) di UPTD Pendidikan Kecamatan Nagrak Kabupaten Sukabumi berjalan dengan sangat baik pada setiap aspek pelaksanaannya.

Apabila dilihat dari indikator pertama yaitu kegiatan menyeleksi peserta pelatihan, Davies (2005, p. 64) menjabarkan bahwa dalam menyeleksi peserta pelatihan, hal-hal yang perlu dilakukan yaitu mempertimbangkan suatu anggota kelompok masyarakat yang memungkinkan untuk dijadikan peserta pelatihan berdasarkan persyaratan yang telah ditentukan sebelumnya, serta mempertimbangkan karakteristik peserta pelatihan. Berdasarkan hasil analisis data yang telah dilakukan, indikator pertama sebanyak $80 \%$ berada pada kategori sangat tinggi dan $20 \%$ pada kategori tinggi. Dari hasil analisis tersebut, maka dapat diketahui bahwa pelatihan Developmentally Appropriate Practice (DAP) sesuai dengan kebutuhan peserta 
JPPM (Jurnal Pendidikan dan Pemberdayaan Masyarakat), 5 (2), 2018 - 146

Fitri Pertiwi, Ishak Abdulhak, Viena Rusmiati Hasanah

pelatihan sebagai seorang pendidik, selain itu panitia juga mencek perlengkapan peserta ketika proses pendaftaran di mana proses pendaftaran dilaksanakan secara tertib.

Indikator kedua yaitu pelaksanaan penilaian awal terhadap peserta pelatihan. Tes awal peserta pelatihan merupakan suatu penilaian yang dilaksanakan untuk mengetahui pengetahuan, keterampilan, serta sikap yang dimiliki oleh peserta sebelum mengikuti proses pembelajaran dalam pelatihan. Berdasarkan hasil analisis data yang telah dilakukan, diperoleh hasil yaitu indikator kedua sebanyak $75 \%$ berada pada kategori sangat tinggi, $15 \%$ pada kategori tinggi, dan 10\% pada kategori sedang. Dari hasil analisis tersebut, dapat diketahui bahwa rata-rata peserta pelatihan memahami bahwa pelaksanaan penilaian awal atau pre-test berfungsi untuk mengukur kemampuan awalnya sebelum mengikuti pelatihan, selain itu panitia juga menjelaskan tata cara menjawab soal pre-test sehingga peserta pelatihan tidak merasa bingung.

Indikator ketiga yaitu pelaksanaan program pelatihan yang mencakup materi pelatihan, metode dan teknik pembelajaran, media pembelajaran, pelatih yang menunjang proses pelatihan, dan kenyamanan tempat. Berdasarkan hasil analisis data yang telah dilakukan, indikator ketiga memiliki nilai yang sangat tinggi yaitu sebanyak 83,33\% berada pada kategori sangat tinggi dan $16,67 \%$ berada pada kategori tinggi. Dari hasil analisis tersebut, dapat diketahui bahwa materi yang disampaikan pada pelatihan Developmentally Appropriate Practice (DAP) bermanfaat bagi para peserta pelatihan dalam melaksanakan kegiatan pembelajaran. Begitu pun dengan penggunaan metode dan teknik pembelajaran, bahwa peserta pelatihan selalu dilibatkan dan diberikan waktu untuk melakukan tanya jawab dan diskusi. Hal ini sesuai dengan pengertian metode dan teknik itu sendiri, sebagaimana yang dikemukakan oleh Fauzi (2011, p. 76) bahwa metode adalah kegiatan yang dipilih sumber belajar untuk mencapai tujuan pendidikan. Sedangkan, teknik adalah langkah-langkah yang ditempuh untuk mengelola kegiatan belajar. Media pembelajaran yang digunakan pun selain membuat materi yang disajikan menjadi menarik, tetapi juga membantu peserta pelatihan untuk lebih memahami materi yang disampaikan, khususnya media pembelajaran berupa handout. Sudjana (2007, p. 164) dan Fauzi (2011, p. 105) juga mengemukakan bahwa tujuan penggunaan handout yaitu untuk meningkatkan pemahaman peserta mengenai materi yang disampaikan melalui lembaran berisi materi pembelajaran secara lengkap. Keunggulan dari media ini yaitu bahan yang diberikan dapat dipergunakan kembali di lain waktu oleh peserta pelatihan. Selain itu, pelaksanaan program pelatihan pun ditunjang oleh kenyamanan tempat pelatihan yang digunakan serta kemampuan pelatih sendiri. Hal ini sejalan dengan pendapat Sudjana (2007, p. 195) bahwa, "Pada dasarnya pelatih adalah pemegang peran utama dalam pembelajaran selama dan setelah pelatihan".

Indikator keempat yaitu pengawasan selama proses pelaksanaan program pelatihan. Berdasarkan hasil analisis data yang telah dilakukan, diperoleh hasil bahwa indikator keempat sebanyak $78,33 \%$ berada pada kategori sangat tinggi, $18,33 \%$ berada pada kategori tinggi, dan $3,33 \%$ berada pada kategori sedang. Dari hasil analisis tersebut, dapat diketahui bahwa pengawasan yang dilakukan oleh pihak panitia selama pelaksanaan kegiatan pelatihan Developmentally Appropriate Practice (DAP) di UPTD Pendidikan Kecamatan Nagrak Kabupaten Sukabumi sudah berjalan dengan baik. Pengawasan selama proses pelaksanaan pelatihan perlu dilakukan untuk mengetahui bahwa pelatihan yang dilaksanakan sesuai dengan tujuan pelaksanaan pelatihan itu sendiri, sehingga pelatihan yang dilaksanakan tidak menyimpang. Hal ini sejalan dengan pendapat Davies (2005, p. 129) yaitu "Penyelenggara pelatihan harus mengawasi program pelatihan secara terus menerus serta membandingkannya dengan panduan dan keseluruhan tujuan pembelajaran".

Indikator terakhir yaitu pelaksanaan penilaian akhir peserta program pelatihan. Berdasarkan hasil analisis data yang telah dilakukan, indikator ini memiliki nilai yang sangat tinggi yaitu sebanyak $80 \%$ berada pada kategori sangat tinggi, dan $\mathbf{2 0} \%$ berada pada kategori tinggi. Dari hasil analisis tersebut, 
JPPM (Jurnal Pendidikan dan Pemberdayaan Masyarakat), 5 (2), 2018 - 147

Fitri Pertiwi, Ishak Abdulhak, Viena Rusmiati Hasanah

dapat diketahui yaitu rata-rata peserta pelatihan setuju bahwa soal penilaian akhir atau post-test sesuai dengan materi yang telah disampaikan.

\section{Kompetensi Pedagogik Pendidik PAUD di Kecamatan Nagrak Kabupaten Sukabumi Setelah Mengikuti Pelatihan Developmentally Appropriate Practice (DAP)}

Hasil penelitian menunjukkan bahwa kompetensi pedagogik pendidik PAUD di Kecamatan Nagrak Kabupaten Sukabumi setelah mengikuti pelatihan Developmentally Appropriate Practice (DAP) berdasarkan indikatornya yang terdiri dari indikator pemahaman wawasan kependidikan mengenai DAP, pemahaman landasan DAP, pemahaman prinsip-prinsip DAP, dan DAP untuk setiap aspek perkembangan pada anak usia 36 tahun dengan jumlah responden sebanyak 6o orang, yaitu dari 50 orang responden dengan jumlah persentase sebesar 83,33\% menunjukkan bahwa kompetensi pedagogik pendidik PAUD di Kecamatan Nagrak Kabupaten Sukabumi setelah mengikuti pelatihan Developmentally Appropriate Practice (DAP) berada pada kategori sangat tinggi, dari 10 orang responden dengan jumlah persentase sebesar 16,67\% menunjukkan bahwa kompetensi pedagogik pendidik PAUD di Kecamatan Nagrak Kabupaten Sukabumi setelah mengikuti pelatihan Developmentally Appropriate Practice (DAP) berada pada kategori tinggi, sedangkan pada kategori sedang, rendah, dan sangat rendah tidak ada responden yang memilih kategori tersebut sehingga persentasenya $0 \%$ Adapun gambarannya dapat dilihat pada tabel berikut.

Tabel 2. Kompetensi Pedagogik Pendidik

PAUD di Kecamatan Nagrak Kabupaten

Sukabumi Setelah Mengikuti Pelatihan DAP

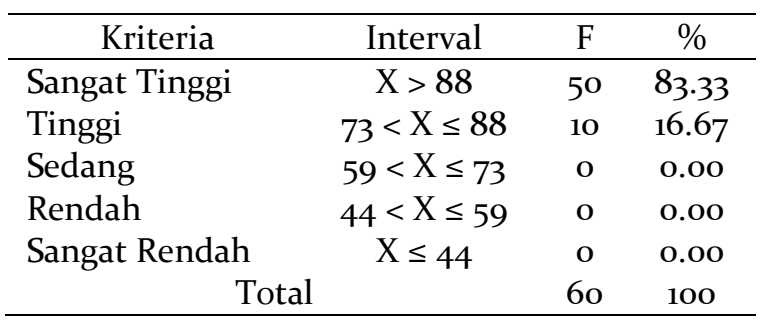

Kompetensi pedagogik adalah kemampuan pendidik dalam mengelola pembelajaran peserta didik (Sudarma, 2013, p. 133). Oleh karena itu, untuk dapat mengelola pembelajaran peserta didik maka terlebih dahulu pendidik harus mengenal karakteristik, minat, dan bakat setiap peserta didiknya. Sehingga setiap kegiatan pembelajaran yang dilaksanakan sesuai dengan karakteristik, minat, dan bakat setiap peserta didik tersebut serta sesuai dengan tugas-tugas pada setiap tahapan perkembangannya.

Pada penelitian ini, kompetensi pedagogik pendidik PAUD di Kecamatan Nagrak Kabupaten Sukabumi setelah mengikuti pelatihan Developmentally Appropriate Practice (DAP) diukur melalui kemampuan para peserta pelatihan dalam menjawab pernyataanpernyataan yang berkaitan dengan kompetensi pedagogik. Hal yang diukur guna mengetahui kompetensi pedagogik pendidik PAUD di Kecamatan Nagrak Kabupaten Sukabumi setelah mengikuti pelatihan Developmentally Appropriate Practice (DAP) yaitu pemahaman wawasan kependidikan mengenai DAP, pemahaman landasan DAP, pemahaman prinsip-prinsip DAP, dan DAP untuk setiap aspek perkembangan pada anak usia 3-6 tahun.

Berdasarkan keseluruhan indikator dari kompetensi pedagogik pendidik PAUD di Kecamatan Nagrak Kabupaten Sukabumi setelah mengikuti pelatihan Developmentally Appropriate Practice (DAP) dapat dikatakan bahwa kompetensi pedagogik pendidik PAUD setelah mengikuti pelatihan Developmentally Appropriate Practice (DAP) mengalami peningkatan. Hal ini dibuktikan oleh hasil analisis data yang telah dilakukan yakni dengan jumlah responden sebanyak 60 orang, yaitu dari 50 orang responden dengan jumlah persentase sebesar $83,33 \%$ menunjukkan bahwa kompetensi pedagogik pendidik PAUD di Kecamatan Nagrak Kabupaten Sukabumi setelah mengikuti pelatihan Developmentally Appropriate Practice (DAP) berada pada kategori sangat tinggi, dan dari 10 orang responden dengan jumlah persentase sebesar 16,67\% menunjukkan bahwa kompetensi pedagogik pendidik PAUD di Kecamatan Nagrak Kabupaten Sukabumi setelah mengikuti pelatihan Developmentally 
JPPM (Jurnal Pendidikan dan Pemberdayaan Masyarakat), 5 (2), 2018 - 148

Fitri Pertiwi, Ishak Abdulhak, Viena Rusmiati Hasanah

Appropriate Practice (DAP) berada pada kategori tinggi. Jumlah persentase yang cenderung berada pada kategori sangat tinggi dan tinggi dari setiap indikator pun dapat menjadi pendukung tambahan bahwa kompetensi pedagogik pendidik PAUD di Kecamatan Nagrak Kabupaten Sukabumi setelah mengikuti pelatihan Developmentally Appropriate Practice (DAP) mengalami peningkatan, yang berarti bahwa pendidik memahami bagaimana cara mengelola kegiatan pembelajaran yang sesuai dengan karakteristik, minat, dan gaya belajar setiap peserta didik, serta sesuai pula dengan tugastugas pada setiap tahapan perkembangan peserta didiknya.

Apabila dilihat dari indikator pertama yaitu pemahaman wawasan kependidikan mengenai DAP, diperoleh hasil bahwa sebanyak $75 \%$ indikator ini berada pada kategori sangat tinggi, dan $25 \%$ berada pada kategori tinggi. Dari hasil analisis data tersebut, dapat disimpulkan bahwa sebagian besar peserta pelatihan memahami bahwa proses pembelajaran yang baik sebaiknya disesuaikan dengan usia anak, disesuaikan dengan setiap individu, serta disesuaikan dengan sosial dan budaya anak. Hal tersebut sesuai dengan yang dikemukakan oleh Wijana, Rama, Siyantayani, Suminah, \& Nurmiati (2011, p. 4.4) bahwa konsep DAP mencakup tiga dimensi, yaitu: (a) kesesuaian usia, maksudnya pendidik memiliki pengetahuan tentang perkembangan anak dalam rentang usia 9 tahun pertama dan kemudian difasilitasi melalui program yang disiapkan dalam lingkungan pembelajaran dan perencanaan yang mengajak anak mengalami pembelajaran yang sesuai dengan usia anak; (b) kesesuaian individu, yaitu karena setiap anak merupakan individu yang unik dengan keunikan dalam kepribadian, gaya belajar, dan latar keluarganya. Oleh karena itu, kurikulum dan interaksi orang dewasa dengan anak harus merespon terhadap perbedaan masing-masing individu; serta; (c) kesesuaian sosial dan budaya, yaitu bahwa setiap anak tidak dapat dipisahkan dari akar budayanya masing-masing, karena mereka sangat dipengaruhi oleh lingkungan budayanya tersebut. Demikian pula dengan lingkungan sosial di mana ia bersosialisasi. Oleh karena itu, jika pendidik memiliki peserta didik dari berbagai lingkungan sosial dan budaya, maka pendidik harus dapat memahami dan memperlakukan anak sesuai dengan sosial dan budaya mereka. Berdasarkan tingginya persentase jawaban para peserta pelatihan yang mencakup ketiga poin di atas, maka dapat disimpulkan bahwa pemahaman wawasan kependidikan pendidik mengenai DAP sangatlah baik.

Indikator kedua yaitu pemahaman landasan DAP yang mencakup memahami kurikulum yang sesuai dengan perkembangan anak, memahami interaksi anak dan orang dewasa, serta hubungan antara program dan rumah. Berdasarkan hasil analisis data yang telah dilakukan, indikator kedua memiliki nilai yang sangat tinggi yaitu sebanyak $80 \%$ berada pada kategori sangat tinggi dan $20 \%$ berada pada kategori tinggi. Dari hasil analisis tersebut, dapat diketahui bahwa sebagian besar pendidik telah memahami kurikulum yang sesuai dengan perkembangan anak, memahami interaksi anak dan orang dewasa dengan cara merespon secara cepat dan langsung terhadap kebutuhan peserta didik serta memberikan peserta didik kesempatan yang beragam untuk berkomunikasi, dan hubungan antara program dan rumah dengan cara pendidik melakukan komunikasi secara rutin dengan orang tua murid, juga menceritakan perkembangan peserta didik kepada orang tuanya. Hal ini didukung oleh pernyataan Wijana, et.al. (2011, p. 4.6) bahwa (a) kurikulum yang sesuai dengan perkembangan anak harus sesuai juga dengan rentang usia anak dalam satu kelompok dan dilaksanakan dengan memerhatikan kebutuhan, minat, dan tingkat perkembangan dari masing-masing anak; (b) interaksi yang sesuai dengan perkembangan anak muncul paling banyak saat anak berinteraksi dengan orang dewasa. Oleh karena itu, perlu adanya keseimbangan interaksi yang diberikan oleh orang dewasa kepada anak; (c) agar proses pembelajaran tercapai secara optimal, maka perlu dilaksanakan pembelajaran secara individu di rumah. Oleh karena itu, pendidik hendaknya membina hubungan dan melakukan komunikasi dengan orang tua anak secara teratur.

Indikator ketiga yaitu pemahaman prinsip-prinsip DAP yang mencakup penga- 
JPPM (Jurnal Pendidikan dan Pemberdayaan Masyarakat), 5 (2), 2018 - 149

Fitri Pertiwi, Ishak Abdulhak, Viena Rusmiati Hasanah

laman pembelajaran aktif, strategi pembelajaran yang beragam, keseimbangan antara pengarahan guru dan kebebasan anak, kurikulum terintegrasi, dan sentra pembelajaran. Berdasarkan hasil analisis data yang telah dilakukan, indikator ketiga sebanyak 78,33\% berada pada kategori sangat tinggi dan sebanyak 21,67\% berada pada kategori tinggi. Dari hasil analisis tersebut, dapat diketahui bahwa sebagian besar pendidik telah memahami cara memberikan pengalaman pembelajaran aktif dengan cara memberikan kesempatan kepada anak untuk mengeksplorasi lingkungannya, memahami cara memberikan strategi pembelajaran yang beragam dengan cara memberikan bermacam-macam cara belajar, memahami keseimbangan antara pengarahan guru dan kebebasan anak dengan cara memberikan panduan pembelajaran kepada anak sebelum proses pembelajaran dimulai, memahami kurikulum terintegrasi dengan cara melaksanakan kegiatan pembelajaran yang sesuai dengan isi kurikulum dan menghubungkannya dengan konteks kehidupan sehari-hari anak, dan memahami sentra pembelajaran. Hal ini sejalan dengan pendapat Wijana, et.al. (2011, p. 4.10) dan Gestwicki (2013, p. 12) bahwa prinsip-prinsip DAP mencakup: (a) pengalaman pembelajaran aktif yaitu memberikan kesempatan kepada anak untuk mengeskplorasi lingkungannya, dengan demikian anak secara bebas dapat menggali dan berinteraksi dengan anak lain maupun orang dewasa; (b) strategi pembelajaran yang beragam yaitu mendorong penggunaan berbagai strategi pembelajaran yang dapat memenuhi kebutuhan anak, dengan memberikan macam-macam cara belajar maka anak-anak dengan gaya belajar yang beragam mampu mengembangkan kemampuan mereka; (c) keseimbangan antara pengarahan pendidik dan kebebasan anak yaitu memberikan keseimbangan antara kegiatan-kegiatan yang perlu pengarahan pendidik dan juga atas inisiatif anak sendiri; (d) kurikulum terintegrasi yaitu menghubungkan area pembelajaran yang beragam dan menggabungkannya dalam konsep terpadu; dan (e) sentra pembelajaran yaitu area mandiri yang dibuat di dalam kelas sehingga anak dapat secara nyata melakukan suatu kegiatan.
Indikator keempat yaitu DAP untuk setiap aspek perkembangan pada anak usia 36 tahun yang mencakup DAP untuk perkembangan fisik, DAP untuk perkembangan sosial/emosional, DAP untuk perkembangan kognitif, dan DAP untuk perkembangan bahasa. Berdasarkan hasil analisis data yang telah dilakukan, indikator keempat memiliki nilai yang sangat tinggi yaitu sebanyak $80 \%$ berada pada kategori sangat tinggi dan $\mathbf{2 0} \%$ berada pada kategori tinggi. Dari hasil analisis tersebut, dapat diketahui bahwa sebagian besar pendidik telah memahami bentuk kegiatan pembelajaran yang dapat menunjang perkembangan fisik anak yaitu perkembangan motorik kasar, motorik halus, dan koordinasi tangan mata, memahami kegiatan yang dapat menunjang perkembangan sosial/ emosional anak yang mencakup menumbuhkan identitas diri anak, memahami bentuk kegiatan pembelajaran yang dapat menunjang perkembangan kognitif anak yang terdiri dari tahap sensorimotor dan tahap operasional, serta memahami bentuk kegiatan pembelajaran yang dapat menunjang perkembangan bahasa anak yang terdiri dari komponen keaksaraan dan lingkungan yang mendukung bahasa. Hal ini sejalan dengan yang dikemukakan oleh Wijana, et.al. (2011, p. 4.16) yaitu (a) gerakan motorik kasar untuk anak usia 3-6 tahun yaitu meliputi berdiri, memanjat, berjalan, berlari, menendang, dan lainnya, sedangkan kemampuan motorik halus untuk anak usia 3-6 tahun antara lain memegang, merobek, menggunting, dan mencoret, adapun koordinasi tangan dan mata dapat dilatih dengan aktivitas membuka bungkus permen, menggunting, dan sebagainya; (b) untuk perkembangan sosial/ emosionalnya maka anak perlu mendapatkan kesempatan untuk banyak berinteraksi, baik dengan anak lain maupun orang dewasa di lingkungan sekitarnya, dalam melakukan interaksi dengan anak maka orang dewasa perlu melakukan kontak mata untuk menumbuhkan identitas diri anak. Karena identitas diri anak akan tumbuh subur jika mendapat perlakuan positif; (c) pada tahap sensorimotor, anak belajar untuk mengetahui dunianya hanya dengan mengandalkan panca indera, yaitu melalui meraba, membau, melihat, mendengar dan merasakan. Sedangkan 
JPPM (Jurnal Pendidikan dan Pemberdayaan Masyarakat), 5 (2), 2018 - 150

Fitri Pertiwi, Ishak Abdulhak, Viena Rusmiati Hasanah

tahap praoperasional merupakan tahap awal pembentukan konsep secara stabil. Penalaran mental mulai muncul, egosentrisme mulai kuat dan kemudian lemah, serta keyakinan terhadap hal yang magis terbentuk; (d) untuk perkembangan bahasa yakni pengetahuan tentang tulisan menggambarkan semua ide yang berhubungan dengan bagaimana tulisan dikelola dan digunakan. Hal ini termasuk pemahaman fungsi tulisan dan variasi huruf yang digunakan. Anak perlu mengetahui bahwa tulisan mengandung pesan dan makna. Adanya tulisan dimana-mana akan membuat anak belajar banyak tentang tulisan.

\section{Pengaruh Pelaksanaan Developmentally Appropriate Practice (DAP) terhadap Peningkatan Kompetensi Pedagogik Pendidik PAUD}

Untuk mengetahui pengaruh pelaksanaan pelatihan Developmentally Appropriate Practice (DAP) terhadap peningkatan kompetensi pedagogik pendidik PAUD, maka harus dilakukan analisis data sebagai berikut.

Pengujian Persyaratan Analisis Parametrik

\section{Hasil Uji Normalitas}

Statistika parametrik yang termasuk ke dalam statistika inferensial memerlukan adanya model distribusi untuk memperkirakan parameter populasi. Data sampel hendaknya memenuhi prasyarat distribusi normal yaitu data yang akan dianalisis dengan statistik parametrik harus mengikuti distribusi normal. Jika sebaran data mengikuti sebaran normal, maka populasi dari mana data diambil berdistribusi normal dan akan dianalisis menggunakan analisis parametrik. Berdasarkan Gambar 1 dan 2, dapat dikatakan bahwa model berdistribusi normal karena data tersebar di sekitar garis normalitas. Pengujian ini dilakukan dengan menggunakan normal probability plot melalui bantuan program komputer IBM SPSS Statistics 20.

\section{Hasil Uji Linearitas}

Langkah-langkah perhitungan uji linearitas adalah sebagai berikut: a) Hipotesis

Ho: Model regresi tidak linear

Hi: Model regresi linear

b) Hasil Pengujian

Hasil pengujian dilihat dari kolom sig. pada baris linearity. Pengujian linearitas ini dilakukan dengan menggunakan bantuan IBM SPSS Statistics 20 dan diperoleh hasil seperti terlihat pada Tabel 3.

c) Proses Pengambilan Keputusan

Proses pengambilan keputusan dilakukan dengan kriteria sebagai berikut: jika $\mathrm{p}<0,05$ maka model regresi linear; jika $\mathrm{p} \geq 0,05$, maka model regresi tidak linear.

d) Kesimpulan

Berdasarkan Tabel 3 diperoleh hasil bahwa nilai p (o,000) lebih kecil dari 0,05. Hal ini berarti bahwa model regresi linear.

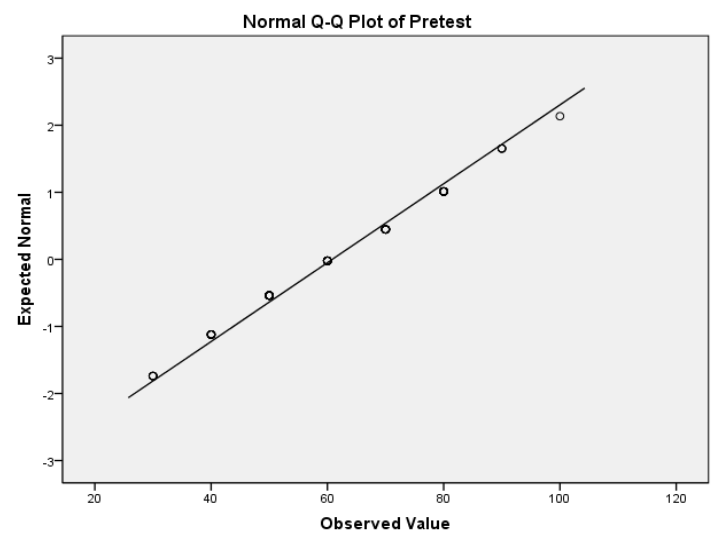

Gambar 1. Normal Q-Q Plot Data Pre-test

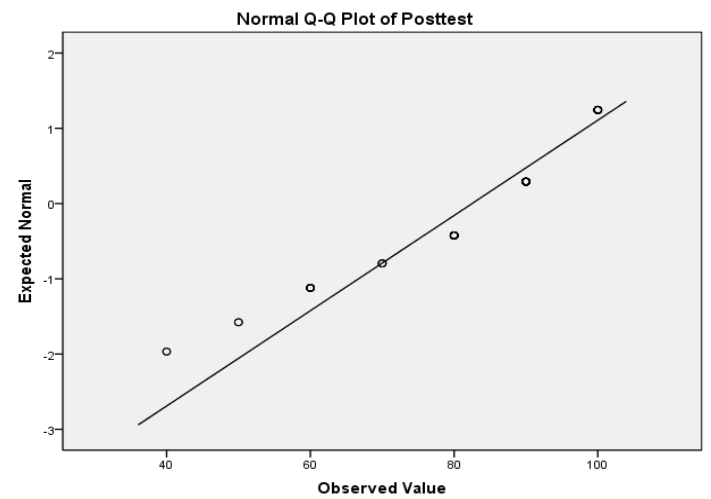

Gambar 2. Normal Q-Q Plot Data Post-test 
JPPM (Jurnal Pendidikan dan Pemberdayaan Masyarakat), 5 (2), 2018 - 151

Fitri Pertiwi, Ishak Abdulhak, Viena Rusmiati Hasanah

Tabel 3. Hasil Uji Linearitas Data

\begin{tabular}{|c|c|c|c|c|c|}
\hline \multicolumn{6}{|c|}{ ANOVA Table } \\
\hline & & Sum of Squares $\mathrm{df}$ & Mean Square & $\mathrm{F}$ & Sig. \\
\hline \multirow{5}{*}{ Posttest * Pretest } & \multirow{3}{*}{$\begin{array}{ll}\text { Between } & \text { (Combined) } \\
\text { Groups } & \text { Linearity } \\
& \text { Deviation from Linearity }\end{array}$} & 5537.5027 & 791.072 & 4.477 & .001 \\
\hline & & $5152.357 \quad 1$ & 5152.357 & 29.162 & .000 \\
\hline & & 385.1456 & 64.191 & .363 & .899 \\
\hline & Within Groups & 9187.49852 & 176.683 & & \\
\hline & Total & 14725.00059 & & & \\
\hline
\end{tabular}

Tabel 4. Uji Perbedaan Dua Rata-Rata Populasi Berhubungan antara Data Pre-test dan Data Post-test Pelaksanaan Pelatihan DAP

\begin{tabular}{lcccc}
\hline \multicolumn{1}{c}{ Perlakuan } & Rata-rata & Sd & Perbedaan Rata-rata & Statistik Uji t \\
\hline Pre-test & 60.8333 & 17.00366 & \multirow{2}{*}{1.66667} & 11.292 \\
Post-test & 82.5000 & 15.79798 & & \\
\hline
\end{tabular}

Uji Perbedaan Dua Rata-Rata Populasi Berhubungan

Uji ini dilakukan untuk mengetahui pengaruh pelaksanaan pelatihan Developmentally Appropriate Practice (DAP) di UPTD Pendidikan Kecamatan Nagrak Kabupaten Sukabumi terhadap peningkatan kompetensi pedagogik pendidik PAUD yang diukur melalui data pre-test dan data post-test. Pada penjelasan sebelumnya telah dijelaskan bahwa data pre-test dan data post-test memenuhi persyaratan analisis parametrik, maka untuk melakukan uji perbedaan dua rata-rata populasi berhubungan antara data pre-test dan data post-test guna membandingkan perubahan yang terjadi antara sebelum dan setelah para peserta pelatihan mengikuti pelaksanaan pelatihan Developmentally Appropriate Practice (DAP), maka digunakan uji t berpasangan (paired sample t-test).

Bentuk rumusan hipotesis yang diuji yaitu:

Ho: $\mu_{\mathrm{A}}=\mu_{\mathrm{B}}$,

pelaksanaan pelatihan Developmentally Appropriate Practice (DAP) tidak berpengaruh secara signifikan terhadap peningkatan kompetensi pedagogik pendidik PAUD.

Hi : $\mu_{\mathrm{A}} \neq \mu_{\mathrm{B}}$,

pelaksanaan pelatihan Developmentally Appropriate Practice (DAP) berpengaruh secara signifikan terhadap peningkatan kompetensi pedagogik pendidik PAUD.

Kriteria pengujiannya yaitu Ho diterima jika $-\mathrm{t}_{1-1 / 2} \alpha<\mathrm{t}_{\text {hitung }}<\mathrm{t}_{1-1 / 2} \alpha$, di mana $\mathrm{t}_{1-1 / 2} \alpha$ diperoleh dari daftar tabel $\mathrm{t}$ dengan $\mathrm{dk}=\mathrm{n}_{1}+$ $\mathrm{n}_{2}-2$ dan peluang $(1-1 / 2 \alpha)$. Sedangkan untuk harga-harga t lainnya, maka Ho ditolak.
Hasil uji perbedaan dua rata-rata populasi berhubungan antara data pre-test dan data post-test dari pelaksanaan pelatihan Developmentally Appropriate Practice (DAP) dengan menggunakan uji $\mathrm{t}$ berpasangan, seperti terlihat pada Tabel 4 .

Harga $t_{(0,975)}$ untuk uji dua sisi pada distribusi t dengan $\mathrm{dk}=60+60-2=118$ maka diperoleh nilai $t_{\text {tabel }}=1,98$. Berdasarkan Tabel 4.14 diperoleh nilai thitung sebesar 11,292. Jika nilai $t_{\text {hitung }}$ dibandingkan dengan nilai $t_{\text {tabel }}$, maka dapat dilihat bahwa $t_{\text {hitung }}(11,292)>t_{\text {tabel }}$ $(1,98)$, sehingga Ho ditolak dan Hi diterima. Dilihat dari perolehan rata-rata pada Tabel 4, diperoleh hasil bahwa data post-test $(82,5000)$ memiliki nilai rata-rata yang lebih besar dibandingkan dengan data pre-test $(60,8333)$. Hal ini berarti bahwa setelah mengikuti pelaksanaan pelatihan Developmentally Appropriate Practice (DAP), ratarata kompetensi pedagogik pendidik PAUD menjadi lebih baik dibandingkan dengan sebelum mengikuti pelaksanaan pelatihan Developmentally Appropriate Practice (DAP), atau dengan kata lain pelaksanaan pelatihan Developmentally Appropriate Practice (DAP) berpengaruh secara signifikan terhadap peningkatan kompetensi pedagogik pendidik PAUD.

Didasarkan atas lebih tingginya ratarata nilai post-test dibandingkan dengan ratarata nilai pre-test, maka dapatlah diketahui bahwa pelaksanaan pelatihan Developmentally Appropriate Practice (DAP) memberikan manfaat dalam meningkatkan kompetensi pedagogik para peserta pelatihan. Hal ini sejalan dengan pendapat Fauzi (2011, p. 14) 
JPPM (Jurnal Pendidikan dan Pemberdayaan Masyarakat), 5 (2), 2018 - 152

Fitri Pertiwi, Ishak Abdulhak, Viena Rusmiati Hasanah

bahwa manfaat pelatihan bagi peserta pelatihan yaitu terjadinya peningkatan pemahaman mengenai bidang pekerjaannya serta tanggung jawabnya terhadap pekerjaan tersebut, serta peningkatan pengetahuan dan keterampilan kerja. Selanjutnya Sudjana (2007, p. 7) menambahkan bahwa kegunaan pelatihan bagi individu atau peserta pelatihan adalah terjadinya peningkatan berbagai kemampuan (competencies) melalui perolehan keterampilan, pengetahuan, sikap dan nilai-nilai baru setelah mengikuti pelatihan, yang ditampilkan dalam pelaksanaan tugas atau pekerjaan dan/atau kehidupan mandiri. Kegunaan pelatihan bagi lembaga atau organisasi adalah tercapainya tujuan-tujuan kelembagaan. Kelembagaan di sini yaitu lembaga Pendidikan Anak Usia Dini yang merupakan sarana untuk menggali dan mengembangkan berbagai potensi anak agar dapat berkembang secara optimal.

Pelaksanaan pelatihan Developmentally Appropriate Practice (DAP) yang berjalan dengan sangat baik pasti akan mempengaruhi tingkat pemahaman peserta pelatihan terhadap materi pelatihan yang disampaikan. Seperti halnya semangat yang ditunjukkan oleh pemateri ketika menyampaikan materi dan juga penguasaan pemateri terhadap materi yang disampaikan, maka akan diikuti pula dengan munculnya semangat belajar peserta pelatihan. Karena, peserta pelatihan akan menyenangi materi pembelajaran apabila pelatih menyenangi materi tersebut. Seiring dengan munculnya semangat belajar dan rasa senang terhadap materi pembelajaran dalam pelatihan, maka akan semakin mudah bagi para peserta pelatihan untuk memahami materi yang disampaikan. Apabila peserta pelatihan telah memahami materi pembelajaran dalam pelatihan, maka hal tersebut akan diikuti pula dengan peningkatan pengetahuan serta kemampuan dan perubahan sikapnya dalam menyusun kegiatan pembelajaran bagi para peserta didiknya. Sehingga tujuan dari lembaga Pendidikan Anak Usia Dini untuk menggali dan mengembangkan berbagai potensi anak secara optimal dapat terwujud melalui kegiatan pembelajaran yang sesuai dengan karakteristik, minat, gaya belajar, dan tahapan perkembangan para peserta didiknya.
Sahertian (Wibowo, 2009, p. 28) mengatakan bahwa, faktor-faktor yang mempengaruhi kompetensi pedagogik pendidik, diantaranya (a) pengetahuan, keterampilan, dan sikap yang dimiliki pendidik; (b) kepemimpinan Kepala Sekolah; dan (c) lingkungan kerja yang mendorong motivasi kerja pendidik untuk meningkatkan pengetahuan, keterampilan, dan sikap dalam pelaksanaan tugas secara optimal". Pada poin pertama disebutkan bahwa pengetahuan, keterampilan, dan sikap yang dimiliki pendidik berpengaruh terhadap kompetensi pedagogik pendidik. Hal ini sesuai dengan kondisi empirik yang diperoleh dari perbandingan rata-rata nilai pre-test dan post-test serta dari hasil angket bahwa dengan keikutsertaan pendidik pada pelaksanaan pelatihan Developmentally Appropriate Practice (DAP), maka secara langsung akan diikuti dengan terjadinya peningkatan pengetahuan dan keterampilan pendidik, serta sikap baru yang dapat mengubah perilaku pendidik tersebut. Peningkatan terhadap ketiga aspek tersebut akan meningkatkan kompetensi pedagogik pendidik itu sendiri. Hal ini sejalan dengan pendapat Amstrong (Mustafah, 2011, p. 62) bahwa, pelatihan bermanfaat untuk membantu pendidik dalam mengembangkan keterampilan dan tingkat kemampuannya”.

\section{DAFTAR PUSTAKA}

Davies, E. (2005). Buku wajib bagi para manajer bagaimana menyelenggarakan training. Jakarta: PT. Gramedia.

Fauzi, I. K. A. (2011). Mengelola pelatihan partisipatif. Bandung: Alfabeta.

Gestwicki, C. (2013). Developmentally appropriate practice: Curriculum and development in early education. Cengage Learning.

Lidinillah, D. A. M. (2012). Developmentally appropriate practice (DAP): penerapannya pada program pendidikan anak usia dini dan sekolah dasar. Retrived from http://file. upi. edu/Direktori/KD-

TASIKMALAYA/DINDIN_ABDUL_MU IZ_LIDINILLAH_ TASIKMALAYA)$197901132005011003 / 132313548$. 
JPPM (Jurnal Pendidikan dan Pemberdayaan Masyarakat), 5 (2), 2018 - 153

Fitri Pertiwi, Ishak Abdulhak, Viena Rusmiati Hasanah

Mustafah, J. (2011). Peningkatan kompetensi guru: melalui pelatihan dan sumber belajar teori dan praktik. Jakarta: Kencana.

Sudarma, M. (2013). Profesi guru: dipuji, dikritisi, dan dicaci. PT Rajagrafindo Persada.

Sudjana, D. (2007). Sistem dan manajemen pelatihan teori dan aplikasi. Bandung: Falah Production.

Syamsidar, S. (2014). Peranan pendidikan dalam memerangi keterbelakangan. AlIrsyad Al-Nafs: Jurnal Bimbingan dan Penyuluhan Islam, 1(1).

Presiden Republik Indonesia. Peraturan pemerintah Republik Indonesia no 19 th 2005 tentang standar nasional pendidikan, Pub. L. No. 19, Peraturan pemerintah Republik Indonesia 1 (2005).

Presiden Republik Indonesia. Undangundang nomor 14 tahun 2005 tentang guru dan dosen (2005). 14. Retrieved from

http://www.sjdih.depkeu.go.id/fullTex t/2005/14TAHUN2005UU.htm

Purwanto, N. A. (2006). Kontribusi Pendidikan Bagi Pembangunan Ekonomi Negara. Jurnal Manajemen Pendidikan, 2(2).

Wibowo, D. (2009). Pengaruh supervisi kepala sekolah dan kompetensi pedagogik guru terhadap kinerja guru SD Negeri Kec. Kersana Kab. Brebes. Thesis. Universitas Negeri Semarang.

Wijana, W. D., Rama, S., Siyantayani, Y., Suminah, E., \& Nurmiati, M. W. (2008). Kurikulum pendidikan anak usia dini. Jakarta: Universitas Terbuka.

Zustiyantoro, D. (2012). Guru bersertifikat wajib uji kompetensi. Universitas Negeri Semarang. Retrived from http://unnes.ac.id/berita/gurubersertifikat-wajib-uji-kompetensi/. 